DOI: $10.25140 / 2411-5363-2021-3(25)-229-236$

УДК 664.681:613.292

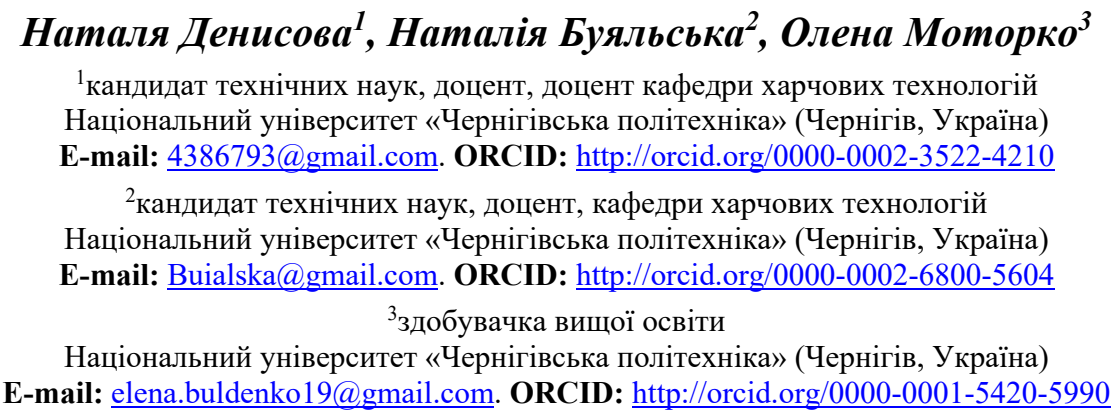

\title{
ДОСЛІДЖЕННЯ ВПЛИВУ ДОБАВОК ВІВСЯНОГО БОРОШНА ТА ЯБЛУЧНОГО ПЮРЕ НА ТЕХНОЛОГІЮ ВИРОБНИЦТВА БІСКВІТІВ
}

Розроблено рецептуру бісквітного напівфабрикату з використанням яблучного пюре та вівсяного борошна. Встановлено, що добавка $5 \%$ та $10 \%$ вівсяного борошна і $10 \%$ яблучного пюре сприяє поліпшенню спожсивчих характеристик випеченого напівфабрикату. Суміш яєць курячих харчових із иукром і яблучним пюре має кращу піноутворювальну здатність, піностійкість, ніж аналогічна з иукром білим кристалічним. Випечені напівфабрикати з яблучним пюре $i$ вівсяним борошном мають більшу масову частку вологи, порівняно з контрольним зразком, проте отримані результати знаходяться в межах норми. Використання яблучного пюре і вівсяного борошна дозволило отримати продукт з поліпшеними показниками якості, високими органолептичними характеристиками та підвищеною харчовою иінністю.

Ключові слова: борочняні кондитерські вироби; бісквіт; вівсяне борочно; яблучне пюре; метод флейвору.

Рис.: 4. Табл.: 2. Бібл.: 14

Актуальність теми дослідження. За останні 10 років в Україні відбувається значне розширення асортименту борошняних кондитерських виробів, нарощування обсягів виробництва всієї продуктової лінійки - від борошняних виробів (близько 54 \% від обсягу продаж) до цукристих кондитерських виробів (близько 18 \%). Бісквітні вироби в структурі обсягів виробництва посідають третє місце. Обмежують поширення даного виду продукції їх висока калорійність та порівняно висока собівартість. До того ж більшість кондитерських виробів бідні на вітаміни та інші біологічно активні речовини, тому постає задача підвищення їх харчової та біологічної цінності.

Перспективним з цієї точки зору є додавання до рецептури бісквіту вівсяного борошна, що за складом амінокислот є наближеним до тваринних білків та відрізняється зниженим вмістом крохмалю і підвищеним вмістом жирів та рослинних харчових волокон [1]. Крім того, вівсяне борошно слугує джерелом таких корисних компонентів, як вітаміни (групи В, Е, А), мікро- та макроелементи (Силіцій, Манган, Селен, Магній, Кальцій, Ферум) [2].

Останнім часом існують технології введення харчових волокон до раціону харчування шляхом використання різноманітного спектра рослинних добавок. Збагачення бісквітів харчовими волокнами рослинної сировини і продуктами іiї переробки дозволяє отримати не тільки збагачений продукт оздоровчого призначення, але і значно підвищити структурно-механічні властивості готових виробів.

3 цього погляду цікавим $є$ використання яблук (концентрати, пюре, пектин, вичавки, порошки) в якості добавки - фруктової сировини, що має збагачений хімічний склад та гарні технологічні властивості, а також використання яких є економічно доцільним для Чернігівського регіону та України загалом. У яблуках містяться вітаміни С, В1, В2, Р, Е, каротин, Калій, Ферум, Манган, Кальцій, пектини, органічні кислоти. Вживання плодів нормалізує травлення, підвищує імунітет, впливає на гормональний фон, поліпшує загальне самопочуття. Низька калорійність дозволяє включать їх в різні дієтичні страви та вироби, спрямовані на оздоровлення або зниження маси тіла [3; 4].

(C) Денисова Н. М., Буяльська Н. П., Моторко О. М., 2021 
Постановка проблеми. Розширення асортименту борошняних кондитерських виробів підвищеної харчової та біологічної цінності, а саме розроблення технології виробництва бісквітного напівфабрикату з використанням альтернативної сировини (борошна вівсяного та яблучного пюре) $є$ актуальним завданням дослідників харчових технологій.

Аналіз останніх досліджень і публікацій. Поліпшенням функціональних властивостей борошняних кондитерських виробів займалися відомі науковці Дорохович В., Іоргачова К., Макарова О., Пащенко В., Кочерга В., Назар М., Бульчук Е. У роботах [5-11] розглянута можливість використання рослинної сировини (продуктів переробки моркви, гарбуза, соняшнику, кукурудзи, глоду, горобини, калини, волоського горіху, обліпихи, яблук, люпину, топінамбуру, кіноа, гречки, амаранту, льону). Доведений позитивний вплив добавок на фізикохімічні та органолептичні властивості бісквітного напівфабрикату. Перспективи подальших досліджень, спрямованих на використання вівсяного борошна та продуктів переробки яблук, можна також знайти в ряді останніх зарубіжних робіт [12-14].

Виділення недосліджених частин загальної проблеми. Аналіз літературних джерел показав, що використання одночасно й альтернативних сортів борошна і рослинних фруктових добавок у виробництві борошняних кондитерських виробів недостатньо вивчено. Додавання вівсяного борошна дозволяє підвищити харчову та біологічну цінність кінцевого продукту, але завдяки зниженому вмісту крохмалю і підвищеному вмісту жирів, фізико-хімічні показники готових виробів погіршуються. У зв'язку з цим необхідно встановити оптимальні концентрації подібних добавок.

Метою статті було дослідження впливу добавок яблучного пюре та вівсяного борошна на фізико-хімічні та органолептичні показники якості бісквітного напівфабрикату.

Виклад основного матеріалу. Об'єкт дослідження - бісквітне тісто, виготовлене 3 різним відсотковим вмістом борошна вівсяного та додаванням яблучного пюре та випечені за традиційними рецептурами з такого тіста бісквіти.

Предмет дослідження - показники якості бісквітного тіста 3 додаванням вівсяного борошна і яблучного пюре й випеченого з нього напівфабрикату.

Бісквітний напівфабрикат - це пишний, дрібнопористий напівфабрикат з м'яким еластичним м'якушем, технологія якого включає збивання яєчного меланжу з цукром-піском, перемішуванням збитої маси з борошном пшеничним і випічкою отриманого напівфабрикату за установлених значень температури та вологості. Рецептура бісквітів може передбачати додавання крохмалю задля зниження кількості клейковини в тісті, запобігання затягування. 3 цією ж метою застосовують ферментні препарати протеолітичної дії. Рецептурний склад бісквітного напівфабрикату змінюється залежно від його виду й подальшого призначення.

При виконанні роботи для виготовлення бісквітних виробів та проведення органолептичних фізико-хімічних та хімічних досліджень була використана така сировина:

- борошно пшеничне вищого гатунку згідно з ДСТУ 46.004-99 «Борошно пшеничне. Технічні умови»;

- вівсяне борошно згідно з ДСТУ 2422-94;

- крохмаль картопляний згідно з ДСТУ 4380:2005 «Крохмаль картопляний. Технічні умови»;

- яйця курячі згідно з ДСТУ 5028:2008 «Яйця курячі харчові. Технічні умови»;

- цукор білий кристалічний згідно 3 ДСТУ 4623:2006 «Цукор білий. Технічні умови»;

- яблучне пюре згідно з ГОСТ 18-268 - 76.

Контроль якості тіста проводили за піноутворювальною здатністю, піностійкістю яєчно-цукрової суміші. 
TECHNICAL SCIENCES AND TECHNOLOGIES

Контроль якості випечених напівфабрикатів визначали за:

- органолептичними показниками: форма та стан поверхні бісквітів, колір, смак та запах.

- пористістю бісквітних напівфабрикатів

- вологістю;

- крихкістю.

Характеристика сировини для випікання дослідних зразків та проведення досліджень: борошно пшеничне вищого гатунку вологістю 14,5 \%, кислотністю - 3,0 град, зольністю - 0,52 \%, та вмістом сирої клейковини 27,0 \%. Вологість яєць курячих $-73 \%$. Вологість вівсяного борошна - 13,5 \%, кислотність 4,2. Вологість яблучного пюре -8 \%.

Під час замісу дослідних зразків використовували заміну пшеничного борошна вівсяним у співвідношенні (\%): $95: 5 ; 90: 10 ; 85: 15 ; 80: 20$, а також додаванням до кожного зразку яблучного пюре в кількості 10 \% від обсягу яєць курячих. Як контрольний було використано зразок тіста того ж рецептурного складу з пшеничним борошном без додавання вівсяного борошна і яблучного пюре.

Досліджували зразки бісквіту контрольного, бісквіту з додаванням яблучного пюре (зразок 1), бісквіту з 5 \% вівсяного борошна і яблучним пюре (зразок 2), бісквіту з додаванням $10 \%$ вівсяного борошна і яблучним пюре (зразок 3), бісквіту з додаванням 15\% вівсяного борошна і яблучним пюре (зразок 4), бісквіту з додаванням 20 \% вівсяного борошна і яблучним пюре (зразок 5). Виготовлення дослідних зразків проводили за методикою пробної лабораторної випічки.

Для пробної лабораторної випічки приймали вихід 250 г, рецептура наведена у табл. 1.

Таблиця 1

Рецептура дослідних зразків бісквіту

\begin{tabular}{|c|c|c|c|c|c|c|c|c|c|c|}
\hline \multirow{4}{*}{ Сировина } & \multirow{4}{*}{ 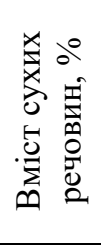 } & \multirow{2}{*}{\multicolumn{2}{|c|}{$\begin{array}{c}\text { Витрата сировини, } \\
\text { кг }\end{array}$}} & \multicolumn{7}{|c|}{ Витрата сировини, г } \\
\hline & & & & \multicolumn{2}{|c|}{$\begin{array}{c}\text { Контрольний } \\
\text { зразок } \\
\end{array}$} & $\begin{array}{c}\text { Зразок } \\
1 \\
\end{array}$ & $\begin{array}{c}\text { Зразок } \\
2 \\
\end{array}$ & $\begin{array}{c}\text { Зразок } \\
3 \\
\end{array}$ & $\begin{array}{c}\text { Зразок } \\
4 \\
\end{array}$ & $\begin{array}{c}\text { Зразок } \\
5 \\
\end{array}$ \\
\hline & & \multicolumn{2}{|c|}{ На 1 т готової фази } & \multicolumn{7}{|c|}{ На 250 г готової фази } \\
\hline & & У натурі & $\begin{array}{c}\text { У сухих } \\
\text { речовинах }\end{array}$ & $\begin{array}{l}\text { У на- } \\
\text { турі }\end{array}$ & \multicolumn{6}{|c|}{ У сухих речовинах } \\
\hline $\begin{array}{l}\text { Борошно пше- } \\
\text { ничне в/Г }\end{array}$ & 85,50 & 281,0 & 240,26 & 70,25 & 60,06 & 60,06 & 56,85 & 53,87 & 53,87 & 47,88 \\
\hline $\begin{array}{l}\text { Яйця курячі } \\
\text { харчові }\end{array}$ & 27,00 & 578,5 & 156,2 & 144,63 & 39,05 & 32,3 & 32,3 & 32,3 & 32,3 & 32,3 \\
\hline $\begin{array}{l}\text { Цукор білий } \\
\text { кристалічний }\end{array}$ & 99,85 & 347,0 & 346,5 & 86,75 & 86,6 & 86,6 & 86,6 & 86,62 & 86,62 & 86,62 \\
\hline $\begin{array}{l}\text { Борошно } \\
\text { вівсяне }\end{array}$ & - & - & - & - & - & - & 3,9 & 7,56 & 11,4 & 14,9 \\
\hline Яблучне пюре & - & - & - & - & - & 2,25 & 2,25 & 2,25 & 2,25 & 2,25 \\
\hline Крохмаль & 80,0 & 69,4 & 55,52 & 17,35 & 13,88 & 13,88 & 10,64 & 12,6 & 11,9 & 11,0 \\
\hline Всього & - & 1275,0 & 908,78 & 318,98 & 199,59 & 199,59 & 192,5 & 195,1 & 198,5 & 194,95 \\
\hline Вихід & 75,00 & 1000,00 & 750,00 & 250,00 & 159,7 & 159,7 & 159,7 & 159,7 & 159,7 & 159,7 \\
\hline
\end{tabular}

Результати проведених досліджень бісквітного напівфабрикату представлено на рис. 1. Встановлено, що при додаванні яблучного пюре до яєчно-цукрової маси, піноутворювальна здатність порівняно з контрольним зразком покращується. При додаванні 5 \% вівсяного борошна до яблучно-яєчної суміші піноутворювальна здатність практично не змінюється. 3 наступним збільшенням вмісту вівсяного борошна - поступово погіршується. 


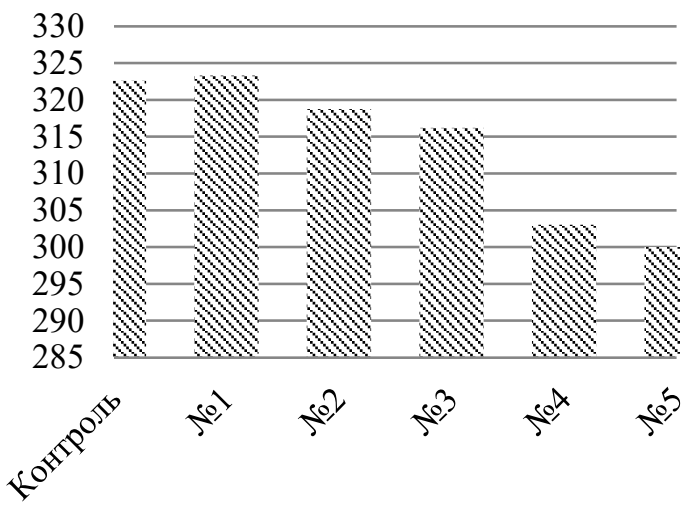

$a$

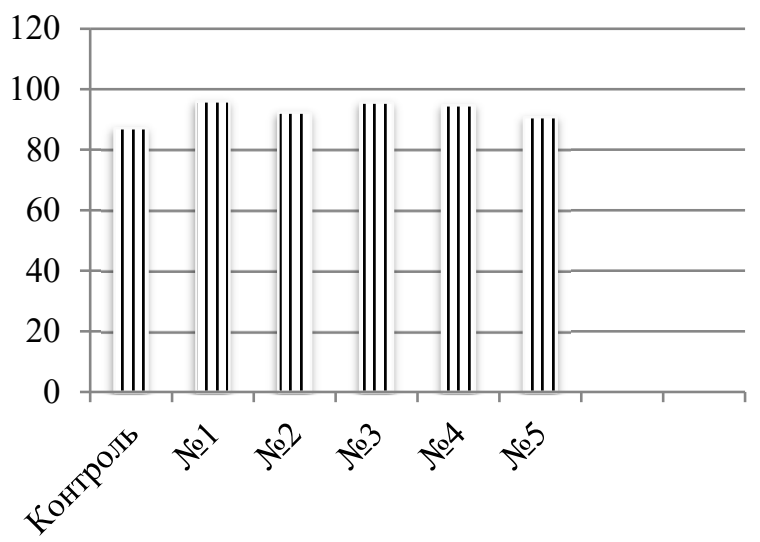

б

Рис. 1. Результати досліджень а) діаграма зміни піноутворювальної здатності (\%) яєчно-иукрової суміші зі збільшенням дозування вівсяного борошна і яблучного пюре;

б) діаграма зміни піностійкості яєчно-иукрової суміші (хвил.).

Виявлено, що стійкість піни зростає при додаванні яблучного пюре, а також при додаванні вівсяного борошна, але зі збільшенням його дозування показники незначно погіршуються. Поліпшення піностійкості зразків із вмістом яблучного пюре обумовлено поверхнево-активними властивостями пектинових речовин. У разі дозування $20 \%$ вівсяного борошна система занадто обтяжується. Пухирці повітря виходять, маса зменшується в об'ємі.

Визначення показників якості випечених напівфабрикатів досліджено органолептичним методом за формою, станом поверхні зразків, кольором, смаком та запахом (табл. 2). Зовнішній вигляд випечених зразків наведено на рис. 2.

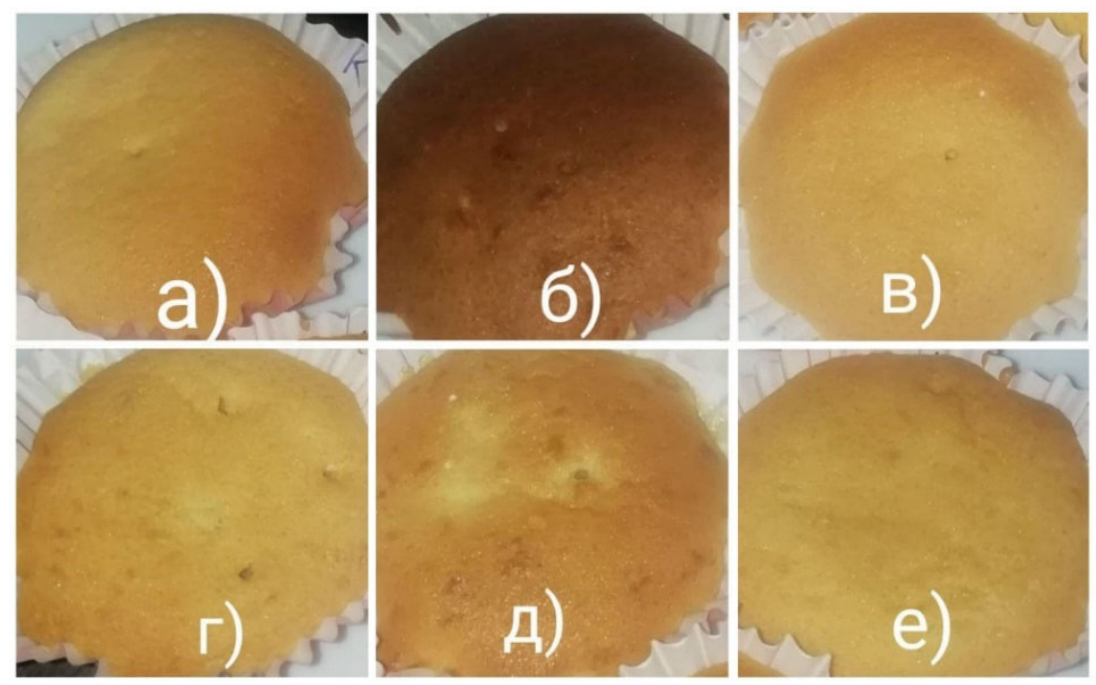

Рис. 2. Зовнішній вигляд випечених зразків:

$а$-контрольного зразка; б-зразка 1; в-зразка 2;

г-зразка 3; д-зразка 4; e-зразка 5

Оцінка органолептичних властивостей зразків проведено методом флейвору. Результат представлено на рис. 3. За площами отриманих багатокутників встановлено, що відношення площ дослідних зразків до площі контрольного зразка становить: 0,$84 ; 0,90$; 0,81; 0,81; 0,77 відповідно, що показує недостатність відносного показника рівню допустимих значень $(0,9)$ зразків $1,3,4,5$. Таким чином, найбільш якісним за результатами $\epsilon$ зразок 2, що має відносний показник у діапазоні $(0,9 \ldots 1)$. 
Органолептичні показники випечених зразків бісквіту

\begin{tabular}{|c|c|c|c|}
\hline \multirow{2}{*}{ Показник } & \multicolumn{3}{|c|}{ Значення } \\
\hline & Контрольний зразок & Зразок 1 & Зразок 2 \\
\hline Форма & Злегка блискуча, випукла & $\begin{array}{c}\text { 3легка блискуча, верхівка } \\
\text { округла } \\
\end{array}$ & $\begin{array}{l}\text { Гладенька, із помітним } \\
\text { блиском по усій площі }\end{array}$ \\
\hline \begin{tabular}{|l|} 
Колір \\
м'якушки
\end{tabular} & Світло-коричневий & Світло-коричневий & Світло-коричневий \\
\hline Запах & $\begin{array}{c}\text { Характерний, без сторонніх } \\
\text { запахів } \\
\end{array}$ & Наявний запах яблука & Наявний запах яблука \\
\hline Смак & $\begin{array}{l}\text { Характерний, приємний, в } \\
\text { міру солодкий }\end{array}$ & $\begin{array}{c}\text { Характерний, приємний, наяв- } \\
\text { ний аромат яблука }\end{array}$ & $\begin{array}{c}\text { Характерний, приємний, } \\
\text { наявний аромат яблука, } \\
\text { в міру солодкий } \\
\end{array}$ \\
\hline Поверхня & $\begin{array}{c}\text { Не підгоріла, поверхня біск- } \\
\text { віту без наявності тріщин і пі- } \\
\text { дривів }\end{array}$ & $\begin{array}{c}\text { Не підгоріла, поверхня біск- } \\
\text { віту без наявності тріщин і пі- } \\
\text { дривів }\end{array}$ & $\begin{array}{c}\text { Не підгоріла, поверхня } \\
\text { бісквіту без наявності } \\
\text { тріщин і підривів } \\
\end{array}$ \\
\hline $\begin{array}{l}\text { Вид } \\
\text { у розламі }\end{array}$ & $\begin{array}{c}\text { Добре пропечений, без слідів } \\
\text { закалу і слідів непромісу }\end{array}$ & $\begin{array}{c}\text { Добре пропечений, без слідів } \\
\text { закалу і слідів непромісу }\end{array}$ & $\begin{array}{c}\text { Добре пропечений, без } \\
\text { слідів закалу і слідів не- } \\
\text { промісу } \\
\end{array}$ \\
\hline \multirow{2}{*}{ Показник } & \multicolumn{3}{|c|}{ Значення } \\
\hline & Зразок 3 & Зразок 4 & 5 \\
\hline Форма & $\begin{array}{c}\text { Гладенька, із помітним блис- } \\
\text { ком по усій площі }\end{array}$ & $\begin{array}{c}\text { Гладенька, із помітним блис- } \\
\text { ком по усій площі }\end{array}$ & $\begin{array}{l}\text { Гладенька, із помітним } \\
\text { блиском по усій площі }\end{array}$ \\
\hline $\begin{array}{l}\text { Колір м’яку- } \\
\text { шки }\end{array}$ & $\begin{array}{c}\text { Світло-коричневий з сірим } \\
\text { відтінком }\end{array}$ & $\begin{array}{c}\text { Світло-коричневий з сірим } \\
\text { відтінком }\end{array}$ & $\begin{array}{c}\text { Світло-коричневий } 3 \text { сі- } \\
\text { рим відтінком }\end{array}$ \\
\hline Запах & $\begin{array}{c}\text { Наявний запах яблука та вів- } \\
\text { сяного борошна }\end{array}$ & $\begin{array}{c}\text { Наявний запах яблука та вівся- } \\
\text { ного борошна }\end{array}$ & $\begin{array}{c}\text { Наявний запах яблука та } \\
\text { сильний запах вівсяного } \\
\text { борошна } \\
\end{array}$ \\
\hline Смак & $\begin{array}{c}\text { Характерний, приємний, наяв- } \\
\text { ний аромат яблука, відчува- } \\
\text { ється аромат вівсяного боро- } \\
\text { шна, в міру солодкий }\end{array}$ & $\begin{array}{c}\text { Характерний, приємний, наяв- } \\
\text { ний аромат яблука, відчува- } \\
\text { ється аромат вівсяного боро- } \\
\text { шна, в міру солодкий }\end{array}$ & $\begin{array}{c}\text { Характерний, приємний, } \\
\text { наявний аромат яблука, } \\
\text { дуже сильно відчува- } \\
\text { ється аромат вівсяного } \\
\text { борошна, в міру солод- } \\
\text { кий } \\
\end{array}$ \\
\hline Поверхня & $\begin{array}{c}\text { Не підгоріла, поверхня біск- } \\
\text { віту, } 3 \text { невеликим підривом } \\
\text { збоку }\end{array}$ & $\begin{array}{c}\text { Не підгоріла, поверхня біск- } \\
\text { віту, з невеликим підривом } \\
\text { збоку } \\
\end{array}$ & $\begin{array}{c}\text { Не підгоріла, поверхня } \\
\text { бісквіту без наявності } \\
\text { тріщин і підривів } \\
\end{array}$ \\
\hline $\begin{array}{l}\text { Вид у роз- } \\
\text { ламі }\end{array}$ & $\begin{array}{c}\text { Добре пропечений, без слідів } \\
\text { закалу і слідів непромісу }\end{array}$ & $\begin{array}{c}\text { Добре пропечений, без слідів } \\
\text { закалу і слідів непромісу }\end{array}$ & $\begin{array}{c}\text { Добре пропечений, без } \\
\text { слідів закалу і слідів не- } \\
\text { промісу }\end{array}$ \\
\hline
\end{tabular}

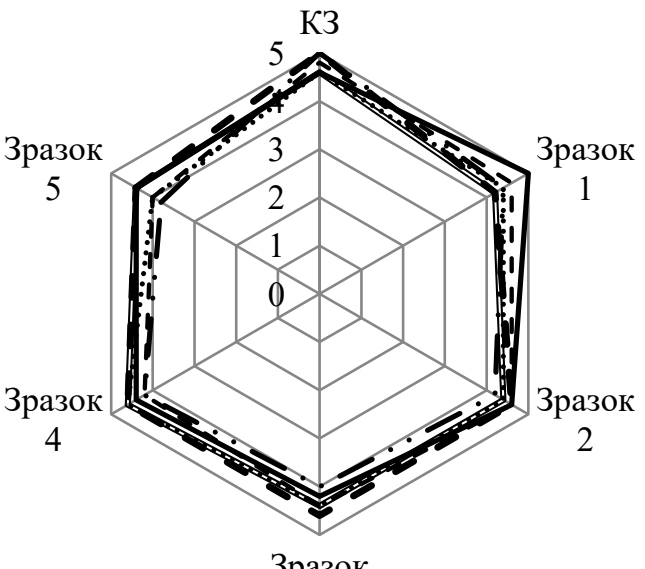

Зразок

$$
\begin{aligned}
& \text {....... Форма } \\
& -\cdots \text { Колір м'якушки } \\
& - \text { Поверхня } \\
& \text { Вид у розламі } \\
& \ldots-\text { Смак } \\
& \text { Запах }
\end{aligned}
$$

Рис. 3. Структурно-механічні та фізико-хімічні показники модельних зразків бісквітного напівфабрикату методом флейвору 
Результати дослідження якісних показників готових бісквітів представлено на рис. 4.

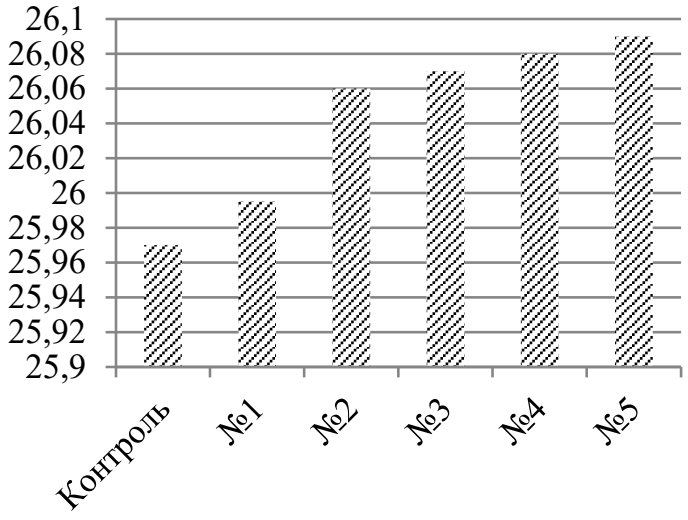

$a$

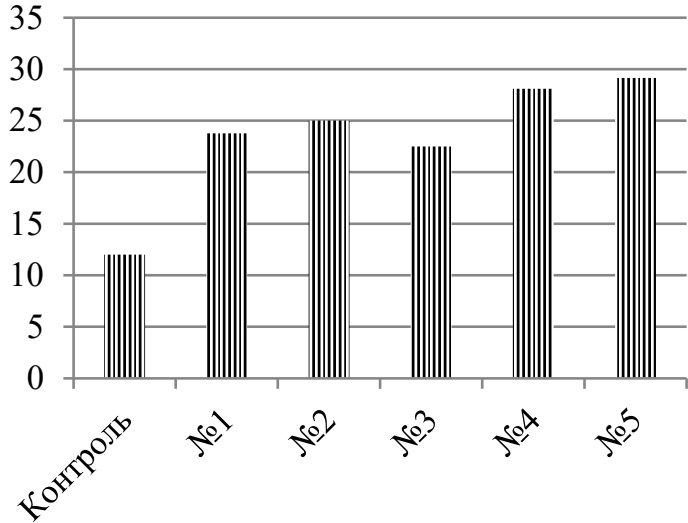

$\sigma$

Рис. 4. Результати досліджень готових зразків:

а) зміна масової частки вологи у різних зразках бісквітного напівфабрикату;

б) діаграма зміни крихкості випечених зразків

Встановлено, що вівсяне борошно у бісквітному напівфабрикаті здатне поглинати більше води та затримувати іiі у випеченому напівфабрикаті, але в незначній мірі. Це можна пояснити високою водо-поглинаючою та волого-утримуючою здатністю вівсяного борошна, яке, приймаючи участь у процесах структурування бісквітного напівфабрикату, проявляє здатність утворювати з рецептурними інгредієнтами нові зв'язки та підвищувати у тісті кількість зв'язаної вологи. Проте всі результати відповідають вимогам нормативно-технічної документації, згідно якої масова частка вологи має складати $(25 \pm 2) \%$.

Високий вміст вівсяного борошна забезпечує надмірну крихкість напівфабрикату, що ускладнює його обробку під час виготовлення тортів та тістечок.

Висновки. Бісквіти, збагачені яблучним пюре та вівсяним борошном мають добрі якісні та технологічні характеристики, що дає напрям щодо подальших досліджень 3 розробки продукції оздоровчого призначення. За фізико-хімічними, структурно-механічними та органолептичними показниками, найкращі характеристики мали зразки 3 додаванням 10 \% яблучного пюре та вівсяного борошна у кількості 5 та $10 \%$.

\section{Список використаних джерел}

1. Ройтер I. М. Сировина хлібопекарного, кондитерського и макаронного виробництв : довідник / І. М. Ройтер , А. А. Макаренкова . - Київ : Урожай, 2003. - 208 с.

2. Технологія кондитерських і хлібобулочних виробів : навч. посіб. / Лисюк Г. М. та ін. ; під ред. Г. М. Лисюк. - Харків : ХДУХТ, 2007. - 412 с.

3. Коломникова Я. П. Способы улучшения рецептуры бисквитного полуфабриката / Я. П. Коломникова, Е. П. Питайкина // Актуальная биотехнология. - 2013. - № 1(4). - С. 27-29.

4. Покращення якості продукції з бісквітного тіста : звіт про науково-дослідну роботу / Хацкевич Ю. М. та ін. - Харків : ХДУХТ, 2012. - 83 с.

5. Влияние мучных композитных смесей на показатели качества бисквитных полуфабрикатов / Иоргачева Е. та ін. // Наукові праці Одеської національної академії харчових технологій. 2009. - Вип. 36(1). - С. 216-221.

6. Дорохович В. В. Застосування морквяного соку при розробленні бісквітів функціонального призначення / В. В. Дорохович // Продукты \& Ингредиенты. - 2013. - № 8. - С. 22-23.

7. Лисюк Г. М. Вплив насіння льону на якість бісквітного напівфабрикату / Г. М. Лисюк, О. Г. Шидакова-Каменюка, О. Чухрай // Прогресивні техніка та технологія харчових виробництв, ресторанного господарства та торгівлі. - 2010. - Вип. 1(11). - С. 260-265. 
8. Назар М. І. Визначення вітамінно-мінерального складу виробів з бісквітного тіста на основі борошняних сумішей і фітокомпозицій / М. I. Назар, В. I. Кочерга // Харчова наука і технологія. - 2012. - № 3(20). - С. 59-62.

9. Філь М. І. Дослідження можливості використання гарбузового порошку в технології бісквітів / М. І. Філь, О. Я. Родак // Продукты \& Ингредиенты. - 2012. - № 4. - С. 16-17.

10. Пащенко В. Л. Плоды боярышника - перспективный ингредиент в технологии производства бисквита / В. Л. Пащенко, Т. Ф. Ильина, Т. И. Ермоленко // Хранение и переработка сельхозсырья. -2010 . - № 3. - С. 56-57.

11. Бульчук Е. Яблочное пюре в технологии бисквита / Е. Бульчук // Хлебопродукты. - 2010. № 1. - C. 36-38.

12. Enhancement of Nutritional Value, Quality and Sensory Properties of Biscuit by Incorporating Oat Flour / Wallaa A. El-Qatey et al. // Journal of Agricultural and Veterinary Sciences. - 2018. Vol. 11, No. 2. - Pp. 213-224.

13. Chemical, Rheological and Sensory Properties of Wheat-oat Flour Composite Cakes and Biscuits / Hoda Zaki et al. // Journal of Productivity and Development. - 2018. - Vol. 23(2). - Pp. 287-306.

14. Development of Apple Pomace Enriched Oat Flour Biscuits and its Quality Evaluation during Storage / Pooja Soni et al. // International Journal of Current Microbiology and Applied Sciences. 2020. - Vol. 9(8). - Pp. 2642-2652.

\section{References}

1. Roiter, Y.M., \& Makarenkova, A.A. (2003). Syrovyna khlibopekarnoho, kondyterskoho y makaronnoho vyrobnytstv: dovidnyk [Raw materials for bakery, confectionery and pasta production: a reference book]. Urozhai.

2. Lysiuk, H.M., Samokhvalova, O.V., Kucheruk, Z.I., Postnova, O.M., Oliinyk, S.H., Artamonova, M.V., Niemirich, O.V., \& Starchaienko, O.T. (2007). Tekhnolohiia kondyterskykh $i$ khlibobulochnykh vyrobiv: navch. posib. [Technology of confectionery and bakery products: study guide]. (H. M. Lysiuk, Ed.). HDUHT.

3. Kolomnikova, Ia.P., \& Pitaikina, E.P. (2013). Sposoby uluchsheniia retceptury biskvitnogo polufabrikata [Ways of the biscuit semi-finished product's recipe improvement]. Aktualnaia biotekhnologiia - Actual biotechnology, 1(4), 27-29.

4. Khatskevych, Yu.M., Seliutina, H.A., Cherevychna, N.I., Olkhovska, V.S., Shcherbakova, T.V., Ovchynnikova, I.F., Tomashevska, R.Ya., Popova, T.M., Bilous, V.I., \& Hapontseva, O.V. (2012). Pokrashchennia yakosti produktsii z biskvitnoho tista: zvit pro naukovo-doslidnu robotu [Improving the quality of biscuit dough products: research report]. HDUHT.

5. Iorgacheva, E.G., Makarova, O.V., Kotuzaki, E.N., \& Kozhokar, N.N. (2009). Vliianie muchnykh kompozitnykh smesei na pokazateli kachestva biskvitnykh polufabrikatov [Influence of flour composite mixes on quality indicators of biscuit semi-finished products]. Naukovi pratsi Odeskoi natsionalnoi akademii kharchovykh tekhnolohii - Scientific works [Odessa national academy of food technologies, 36(1), 216-221.

6. Dorokhovych, V.V. (2013). Zastosuvannia morkvianoho soku pry rozroblenni biskvitiv funktsionalnoho pryznachennia [The use of carrot juice in the development of biscuits of functional purpose]. Produkty \& Ingredienty - Food \& Ingredients, 8, 22-23.

7. Lysiuk, H.M., Shydakova-Kameniuka, O.H., \& Chukhrai, O. (2010). Vplyv nasinnia lonu na yakist biskvitnoho napivfabrykatu [Influence of flax seeds on the quality of biscuit semi-finished product]. Prohresyvni tekhnika ta tekhnolohiia kharchovykh vyrobnytstv, restorannoho hospodarstva ta torhivli-Progressive equipment and technologies of food production, restaurant business and trade, 1 (11), 260-265.

8. Nazar, M.I., \& Kocherha, V.I. (2012). Vyznachennia vitaminno-mineralnoho skladu vyrobiv z biskvitnoho tista na osnovi boroshnianykh sumishei i fitokompozytsii [Determination of vitamin and mineral composition of products from biscuit dough based on flour mixtures and phytocomposition]. Kharchova nauka i tekhnolohiia - Food Science and Technology, (3(20)), 59-62.

9. Fil, M.I., \& Rodak, O.Ia. (2012). Doslidzhennia mozhlyvosti vykorystannia harbuzovoho poroshku $\mathrm{v}$ tekhnolohii biskvitiv [The study of the possibility of using pumpkin powder in biscuit technology]. Produkty \& Ingredienty - Food \& Ingredients, 4, 16-17. 
10. Pashchenko, V.L., Ilina, T.F., \& Ermolenko, T.I. (2010). Plody boiaryshnika - perspektivnyi ingredient $\mathrm{v}$ tekhnologii proizvodstva biskvita [Hawthorn fruit - a promising ingredient in biscuit production technology]. Khranenie i pererabotka selkhozsyria - Storage and processing of farm products, 3, 56-57.

11. Bulchuk, E. (2010). Iablochnoe piure $\mathrm{v}$ tekhnologii biskvita [Apple puree in the biscuit production technology]. Khleboprodukty - Bakery products, 1, pp. 36-38.

12. Wallaa A. El-Qatey, Mohamed, G.E., Gadallah, \& Zainb A. Shabib. (2018). Enhancement of Nutritional Value, Quality and Sensory Properties of Biscuit by Incorporating Oat Flour. Journal of Agricultural and Veterinary Sciences, 11(2), 213-224.

13. Hoda M. Zaki, Elshawaf, A.M., Makhzangy, A.El., \& Hussein, A.M.S. (2018). Chemical, Rheological and Sensory Properties of Wheat-oat Flour Composite Cakes and Biscuits. Journal of Productivity and Development, 23(2), 287-306.

14. Pooja Soni, Sharma, K.D., Sakshi Sharma, Vivek Mehta, \& Surekha Attri (2020). Development of Apple Pomace Enriched Oat Flour Biscuits and its Quality Evaluation during Storage. International Journal of Current Microbiology and Applied Sciences, 9(8), 2642-2652.

Отримано 12.08.2021

UDC 664.681:613.292

\section{Natalya Denisova ${ }^{1}$, Nataliia Buialska ${ }^{2}$, Olena Motorko ${ }^{3}$}

${ }^{1} \mathrm{PhD}$ in Technical Sciences, Associate Professor, Associate Professor of the Department of Food Technologies Chernihiv Polytechnic National University (Chernihiv, Ukraine)

E-mail: 4386793@gmail.com. ORCID: http://orcid.org/0000-0002-3522-4210

${ }^{2} \mathrm{PhD}$ in Technical Sciences, Associate Professor, Associate Professor of the Department of Food Technologies Chernihiv Polytechnic National University (Chernihiv, Ukraine)

E-mail: Buialska@gmail.com. ORCID: http://orcid.org/0000-0002-6800-5604

${ }^{3}$ Student

Chernihiv Polytechnic National University (Chernihiv, Ukraine)

E-mail: elena.buldenko19@gmail.com. ORCID: http://orcid.org/0000-0001-5420-5990

\section{THE STUDY OF INFLUENCE OF OAT FLOUR AND APPLESAUCE ADDITIVES ON THE BISCUIT PRODUCTION TECHNOLOGY}

The use of oat flour and applesauce increases the content of dietary fiber, micronutrients and macronutrients, as well as vitamins in biscuits. Thanks to this, biscuits can be used as valuable food products in order to obtain a balanced diet and expand the range of health food products.

Expanding the range of confectionery products of increased nutritional and biological value, namely the development of a technology of biscuit semi-finished products with adding oat flour and applesauce, is an urgent task for researchers in the field of food technologies.

Preliminary studies for identification of the optimal concentrations of added ingredients in order to prevent a decrease in the quality of the finished product are needed for developing the technology of enriched biscuits obtained by adding of oat flour and applesauce.

An analysis of previously published works showed that to date in the scientific literature little attention has been paid to the use of oat flour and apple processing products in biscuit technology.

The aim of the paper is to study the influence of additives of oat flour and applesauce on the physical, chemical and organoleptic indicators of the quality of the biscuit semi-finished product.

The production of experimental samples was carried out according to the laboratory baking method. When kneading the experimental samples, the replacement of wheat flour with oat one was used in ratio (\%): $95: 5 ; 90: 10 ; 85: 15 ; 80: 20$. Besides, applesauce in the amount of $10 \%$ of volume of melange was added to each sample. On the basis of physical, chemical, structural, mechanical and organoleptic indicators, the best characteristics were obtained for samples of biscuits with a content of $10 \%$ of applesauce and 5 or $10 \%$ of oat flour.

Keywords: flour confectionery, biscuit; oat flour; applesauce; flavor method.

Fig.: 4. Tables: 2. References: 14.

Денисова Н., Буяльська Н., Моторко О. Дослідження впливу добавок вівсяного борошна та яблучного пюре на технологію виробництва бісквітів. Технічні науки та технології. 2021. № 3(25). С. 229-236. 